Original Research Paper

\title{
Identifikasi Miskonsepsi Siswa pada Materi Usaha dan Energi
}

\author{
Maison $^{1 *}$, Neneng Lestari ${ }^{1}$, Anjas Widaningtyas ${ }^{1}$ \\ ${ }^{1}$ Pendidikan Fisika, Universitas Jambi, Jambi, Indonesia.
}

DOI: 10.29303/jppipa.v6i1.314

Sitasi: Maison, Lestari, N., Widaningtyas, A. 2020. Identifikasi Miskonsepsi Siswa pada Materi Usaha dan Energi. Jurnal Penelitian Pendidikan IPA (JPPIPA). 6(1). pp. 32-39

\section{Article history}

Received: August $25^{\text {th }} 2019$

Revised: October $31^{\text {th }} 2019$

Accepted: November $6^{\text {th }} 2019$

*Corresponding Author:

Maison: Pendidikan Fisika,

Universitas Jambi, Jambi,

Indonesia;

Email: maison@unja.ac.id

\begin{abstract}
This study aims to find out how misconceptions experienced by high school students on work and energy material. The method used is a mixed-research method. Data collection was carried out on 288 science students of grade XI at State Senior High School 8 in the City of Jambi using instruments in the form of four-tier diagnostic tests and interviews. The results showed that the average misconceptions experienced by students in the work and energy materials are classified in the low category because the average percentage obtained is 24\%. The sub-concept sequences identified were the misconceptions of which had the highest percentage, namely: effort and potential energy $(80 \%)$; the relationship between kinetic energy, potential energy, and mechanical energy (43\%); and positive and negative efforts $(23 \%)$.
\end{abstract}

Keywords: Identification; misconception; effort and energy

Abstrak: Penelitian ini bertujuan untuk mengetahui bagaimana miskonsepsi yang dialami siswa SMA pada materi usaha dan energi. Metode yang digunakan adalah metode penelitian campuran (mixed-method research). Pengumpulan data dilakukan terhadap 288 siswa kelas XI MIA SMA Negeri 8 Kota Jambi menggunakan instrument berupa tes diagnostik berformat four-tier dan wawancara. Hasil penelitian menunjukkan bahwa rata-rata miskonsepsi yang dialami siswa pada materi usaha dan energi digolongkan dalam kategori rendah karena jumlah persentase yang diperoleh $<30 \%$ yaitu sebesar $24 \%$. Urutan sub konsep yang teridentifikasi miskonsepsi dari yang memiliki persentase tertinggi yaitu: Usaha dan energi potensail (80\%); hubungan antara energi kinetik, energi potensial, dan energi mekanik (43\%); dan usaha positif dan negatif (23\%).

Kata Kunci: Identifikasi; miskonsepsi; usaha dan energi

\section{Pendahuluan}

Pencapaian kompetensi melalui proses belajar mengajar di kelas sering mengalami hambatan yang disebabkan oleh banyak faktor, misalnya lingkungan belajar (Maison, et al., 2019) dan kesalahan siswa dalam memahami konsep yang diajarkan. Pemahaman konsep yang keliru oleh siswa bukan hanya disebabkan oleh proses pembelajaran di kelas, melainkan juga karena adanya konsep awal (prakonsepsi) yang dibawa siswa ke kelas (Ismail, et al., 2017).

Pemahaman siswa terhadap suatu konsep yang berawal dari konsep yang salah tentunya akan berbeda dengan pemahaman ilmiah yang dimiliki oleh pakar atau ilmuwan dalam bidang tersebut, sehingga hanya dapat diterima dalam kasus-kasus tertentu, namun tidak berlaku pada kasus-kasus lain dan tidak dapat digeneralisasikan (Irwansyah, et al., 2018). Hal ini juga didukung pendapat dari Wadana dan Maison (2019) yang mengatakan bahwa dalam proses pembelajaran, akan ditemukannya perbedaan konsepsi siswa dengan konsepsi ilmiah. Konsepsi atau penafsiran konsep yang tidak sesuai dengan pengertian ilmiah atau pengertian yang dimiliki para pakar dalam bidang itu disebut salah konsep atau miskonsepsi (Suana, 2014; Berek, et al., 2016). Masalah miskonsepsi dalam berbagai bidang sains terutama fisika telah lama dan banyak diungkap oleh penelitipeneliti dari berbagai tempat, dimana bidang fisika merupakan cabang ilmu pengetahuan alam yang membahas fenomena dalam kehidupan sehari-hari 
(Hidayati, 2016; Diani, et al., 2019). Bidang mekanika berada diurutan teratas dari bidang-bidang fisika yang mengalami miskonsepsi. Usaha dan energi merupakan salah satu topik yang cukup kompleks yang terdapat dalam bidang mekanika. Kompleksitasnya dapat dilihat dari hubungan antara konsep-konsep (Sudarmini \& Hadiwijaya, 2015; Khaerunnisak, 2018). Karena, pada hakikatnya mempelajari fisika tidak lepas dari fakta, konsep, hukum, dan teori dalam memecahkan masalah terutama di kehidupan seharihari (Herliandry \& Harjono, 2019; Siswadi, et al., 2018). Pembelajaran fisika tersebut siswa diharapkan dapat beraktivitas selayaknya para ilmuan yang membangun konsep dan menerapkan konsep yang telah diterimanya (Nasir, et al., 2015). Pada materi usaha dan energi dibahas mengenai usaha, energi (energi kinetik dan energi potensial), hukum kekekalan energi mekanik, hukum kekekalan energi umum, gaya konservatif dan nonkonservatif, serta daya.

Saheb, et al., (2018) menjelaskan bahwa 21,59\% siswa SMA di Bondowoso mengalami miskonsepsi pada materi usaha dan energi sebesar 21,59\%. Selanjutnya (Zafitri, et al., 2018) menjelaskan bahwa miskonsepsi teridentifikasi disetiap konsep pada materi usaha dan energi dengan rata-rata sebesar $41,07 \%$. Nugraha (2014) menunjukkan bahwa siswa cenderung mengalami miskonsepsi pada usaha positif dan usaha negatif, usaha total oleh gaya konservatif dan gaya nonkonservatif, serta hukum konservasi energi mekanik.

Berdasarkan hasil penelitian sebelumnya dan untuk mendapatkan gambaran awal mengenai kondisi siswa di sekolah, peneliti melakukan wawancara dengan salah satu guru bidang studi fisika di SMA Negeri 8 Kota Jambi. Berdasarkan hasil wawancara didapatkan infromasi bahwa, pada materi usaha dan energi kesulitan yang dialami siswa terletak pada konsep energi potensial. Guru belum mengetahui bahwa dalam pembelajaran fisika sering terjadi miskonsepsi, begitu pula pada materi usaha dan energi. Guru juga belum pernah melakukan tes diagnostik untuk mengetahui apakah dalam pembelajaran fisika ada siswa yang kurang memahami konsep atau mengalami miskonsepsi. Jika ada siswa yang nilai ulangan fisikanya di bawah KKM, guru hanya memberikan remedial dengan meminta siswa mengerjakan ulang soal ujian.

Berbagai teknik pengukuran telah digunakan untuk mengetahui miskonsepsi seseorang baik dalam penelitian nasional maupun international (KaltakciGurel, et al., 2017). Salah satu teknik pengukuran yang dapat digunakan untuk mengidentifikasi miskonsepsi siswa yaitu dengan memberikan tes diagnostik (Susanti, et al., 2014). Instrument tes diagnostik untuk mengidentifikasi miskonsepsi siswa sudah banyak dikembangkan salah satunya yaitu tes diagnostik berformat four-tier ( Kaltakci-Gurel, et al., 2017; Diani et al., 2019). Dengan menggunakan tes four-tier dapat membantu dalam mengungkapkan tingkat kepercayaan siswa mengenai seberapa besar kepercayaan diri siswa tentang alasan jawaban yang mereka berikan. Hasil penilaian dari tes tersebut dapat menginformasikan tentang tingkat pemahaman konseptual siswa (Yang \& Lin, 2015).

Sebagaimana telah dijelaskan sebelumnya, di SMA Negeri 8 Kota Jambi guru belum pernah melakukan tes diagnostik untuk mengetahui miskonsepsi siswa, sehingga data mengenai miskonsepsi siswa belum ada. Padahal, miskonsepsi yang terjadi pada siswa perlu diketahui agar tidak mengganggu dan menghambat proses pembelajaran pada konsep selanjutnya. Penelitian ini dilakukan dengan tujuan untuk mengidentifikasi miskonsepsi siswa agar diperoleh informasi yang berguna untuk perbaikan proses pembelajaran.

\section{Metode}

Berdasarkan tujuan penelitian, jenis penelitian yang digunakan yaitu mixed methods atau penelitian campuran. Desain yang digunakan dalam penelitian ini yaitu sequential explanatory. Responden penelitian yaitu seluruh siswa kelas XI MIA SMA Negeri 8 Kota Jambi yang berjumlah 288 orang. Selanjutnya untuk pemilihan siswa yang akan diwawancarai menggunakan teknik purposive sampling. Pertimbangan yang dijadikan sebagai dasar dalam pengambilan sampel ini adalah siswa yang mengalami miskonsepsi dalam menjawab soal yang diberikan.

Prosedur penelitian terdiri atas beberapa tahapan. Tahap pertama yaitu pendahuluan, penelitian diawali dengan studi literatur dan studi pendahuluan. Tahap ke dua adaptasi instrument. Tahap ke tiga pengumpulan data. Tahap ke empat analisis data secara kuantitatif dan kualitatif, interpretasi dan pengambilan kesimpulan.

Teknik pengumpulan data dalam penelitian ini menggunakan tes, wawancara, dan dokumentasi. Tes yang digunakan berupa tes diagnostik berformat fourtier. Wawancara dilakukan untuk memperkuat jawaban siswa yang mengalami miskonsepsi. Data penelitian yang diperoleh dengan teknik dokumentasi yaitu berupa daftar nama siswa-siswi yang menjadi responden dalam penelitian, hasil tes, foto dokumentasi pada saat pelaksanaan, dan dokumen lain yang mendukung.

Instrumen yang digunakan dalam penelitian berupa tes diagnostik berformat four-tier dan pedoman wawancara. Instrument penelitian diadaptasi dari Jubaedah, et al., (2017), yang mengembangkan tes diagnostik berformat four-tier untuk mengidentifikasi 
miskonsepsi siswa pada topik usaha dan energi. Tes diagnostik berformat four-tier ini terdiri atas empat tingkatan. Tingkatan pertama yaitu soal pilihan ganda beserta jawaban, tingkat ke dua yaitu tingkat keyakinan terhadap jawaban, tingkat ke tiga berupa alasan terhadap jawaban yang diberikan, dan yang ke empat yaitu tingkat keyakinan dari alasan. Pedoman wawancara digunakan untuk mewawancarai siswa yang mengalami miskonsepsi setelah diberikan tes diagnostik berformat four-tier.

Analisis data kuantitatif yaitu dengan mencari skor benar; false positive, false negative, dan $L K$; serta mencari skor miskonsepsi. Selanjutnya setelah data selesai dianalisis peneliti mengelompokkan tingkat miskonsepsi siswa sesuai besar persentasenya, serta mengidentifikasi pada sub konsep apa saja siswa mengalami miskonsepsi. Beberapa kategori miskonsepsi berdasarkan besar persentasenya dapat dilihat pada tabel 1 .

Tabel 1 Kategori Persentase Tingkat Miskonsepsi

\begin{tabular}{ll}
\hline Persentase & Kategori \\
\hline $0 \%-30 \%$ & Rendah \\
$>30 \%-60 \%$ & Sedang \\
$>60 \%-100 \%$ & Tinggi \\
\hline
\end{tabular}

(Suwarno dalam Saheb, et al., 2018)

Hasil dari wawancara berupa data kualitatif, sehingga analisis wawancara menggunakan model Miles \& Huberman. Menurut Miles \& Huberman (Gunawan, 2015) ada tiga tahapan yang harus dikerjakan dalam menganalisis data penelitian kualitatif, yaitu (1) reduksi data (data reduction); (2) paparan data (data display); dan (3) penarikan kesimpulan dan verifikasi (conclusion drawing/verifying).

\section{Hasil dan Pembahasan}

Nilai hasil belajar yang didapat dari penenlitian ini Setelah dilakukannya penelitian, diperoleh hasil persentase rata-rata skor benar. Berikut ini hasil analisis data untuk skor benar:

Tabel 2. Hasil Persentase Rata-Rata Skor Benar

\begin{tabular}{lllllll}
\hline & $\mathbf{1}$ & $\mathbf{2}$ & $\mathbf{3}$ & $\mathbf{4}$ & $\mathbf{5}$ & Mean \\
\hline Hanya Tier 1 & 57 & 2 & 45 & 28 & 15 & 29.40 \\
Hanya Tier & 32 & 0.35 & 36 & 23 & 14 & 21.07 \\
1\&3 & 29 & 0 & 29 & 20 & 12 & 18 \\
Semua Tier & 29 &
\end{tabular}

Berdasarkan Tabel 2 dapat diketahui bahwa persentase rata-rata siswa yang menjawab benar untuk tingkat pertama yaitu sebesar $29 \%$, tingkat pertama dan tingkat ke tiga sebesar $21 \%$, sedangkan persentase rata-rata skor benar untuk semua tingkat atau yang memahami konsep pada materi usaha dan energi digolongkan ke dalam kategori rendah karena jumlah persentase memahami konsep yang diperoleh $<30 \%$ yaitu sebesar $18 \%$.

Selanjutnya jika tabel 1 dinyatakan dalam bentuk grafik yang dapat melukiskan persentase skor benar siswa untuk tingkat pertama, kemudian tingkat pertama dan ke tiga serta semua tingkat, maka akan diperoleh hasil seperti pada gambar 1 .

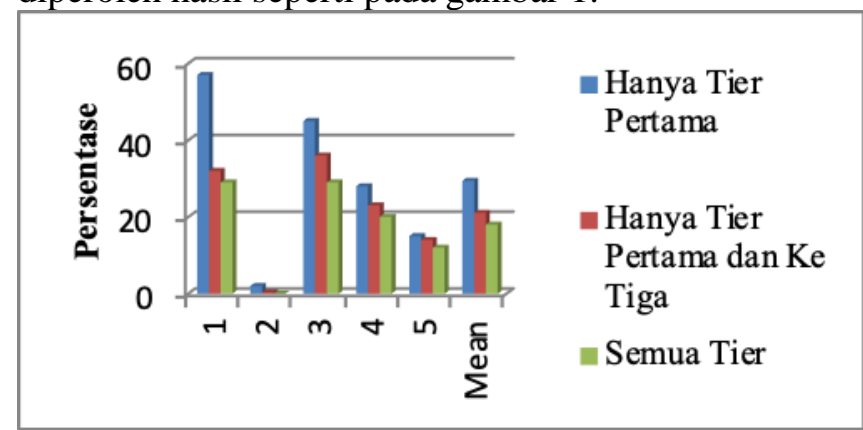

Gambar 1. Persentase rata-rata skor benar setiap item

Berdasarkan Gambar 1 dapat dilihat bahwa urutan skor benar dari yang memiliki persentase tertinggi yaitu skor benar untuk tingkat pertama, kemudian tingkat pertama dan ketiga, dan skor benar untuk semua tingkat. Rata-rata skor benar untuk tingkat pertama dari semua item soal yaitu sebesar 29\%. Persentase skor benar untuk tingkat pertama selalu lebih tinggi. Hal ini dikarenakan bentuk instrument soal seperti soal pilihan ganda biasa, alasan serta tingkat keyakinan siswa dalam memilih jawaban tidak dilihat sehingga apabila siswa menjawab benar skor nilai 1 . Siswa yang menjawab benar untuk tingkat pertama belum dikatakan sepenuhnya memahami konsep, karena jawaban benar ada dua kemungkinan. Pertama siswa menjawab benar karena memang memahami konsep, kedua siswa menjawab benar karena hanya menebak.

Selanjutnya skor benar untuk tingkat pertama dan ke tiga persentasenya yaitu sebesar $21 \%$ lebih rendah dari skor benar tingkat pertama. Hal ini dikarenakan skor benar untuk tingkat pertama dan ketiga penskorannya dilihat dari jawaban dan juga alasan siswa. Apabila jawaban dan alasan benar skor nilai 1 . Kemudian apabila jawaban benar dan alasan salah atau sebaliknya jawaban salah dan alasan benar skor nilai 0 . Selanjutnya skor benar untuk semua tingkat persentase rata-ratanya yaitu sebesar 18\% lebih rendah dari skor benar tingkat pertama dan ke tiga. Hal ini dikarenakan skor benar untuk semua tingkat penskorannya dilihat dari jawaban, alasan, dan tingkat keyakinan siswa dalam memilih jawaban dan alasan. Apabila jawaban dan alasan benar, serta tingkat keyakinan dalam memilih jawaban dan alasan yakin skor nilai 1. Kemudian apabila diantara ke empat tingkat tersebut ada yang salah atau tidak yakin skor nilai 0 . Hasil persentase false positive, false negative, dan $L K$ disajikan pada Tabel 3. 
Tabel 3. Persentase False Positive, False Negative, dan LK

\begin{tabular}{lllllll}
\hline & $\mathbf{1}$ & $\mathbf{2}$ & $\mathbf{3}$ & $\mathbf{4}$ & $\mathbf{5}$ & Mean \\
\hline FP & 24 & 1 & 7 & 4 & 1 & 7.40 \\
FN & 13 & 7 & 6 & 10 & 1 & 7.40 \\
LK & 19 & 7 & 16 & 15 & 9 & 13.20 \\
\hline
\end{tabular}

Keterangan:

$\mathrm{FP}=$ False Positive (kesalahan positif)

$\mathrm{FN}=$ False Negative (kesalahan negatif)

$\mathrm{LK}=$ Lack of Knowledge (kurangnya pengetahuan)

Siswa dikategorikan mengalami false positive apabila dalam menjawab soal yang diberikan siswa menjawab benar dan yakin terhadap jawabannya, tetapi alasan salah dan yakin terhadap alasannya. Selanjutnya untuk kategori false negative kebalikan dari false positive yaitu, apabila jawaban salah dan yakin terhadap jawabannya, tetapi alasan benar dan yakin terhadap alasannya.

Berdasarkan Tabel 3 dapat diketahui bahwa false positive dengan persentase tertinggi yaitu pada soal nomor 1 sebesar $24 \%$ dan false positive terendah yaitu pada soal nomor 2 dan 5 sebesar 1\%. Sedangkan rata-rata false positive dari semua item soal yaitu sebesar $7.4 \%$. Kemudian untuk false negative persentase tertinggi juga pada soal nomor 1 sebesar $13 \%$ dan false negative terendah juga pada soal nomor 5 sebesar $1 \%$. Sedangkan rata-rata false negative dari semua item soal juga sama dengan false positive yaitu sebesar 7.4\%. Selanjutnya lack of knowledge (kurangnya pengetahuan) persentase tertinggi yaitu pada soal nomor 1 sebesar $19 \%$ dan yang terendah yaitu pada soal nomor 2 sebesar $7 \%$. Sedangkan ratarata lack of knowledge untuk semua item soal sebesar $13 \%$. Berdasarkan uraian diatas dapat disimpulkan bahwa siswa yang kurang pengetahuan dalam materi usaha dan energi yaitu sebesar $13 \%$. Hasil persentase rata-rata skor miskonsepsi terdapat pada Tabel 4.

Tabel 4. Hasil Persentase Rata-Rata Skor Miskonsepsi

\begin{tabular}{llllllll}
\hline & M1 & M2 & M3 & M4 & M5 & M6 & Mean \\
\hline $\begin{array}{l}\text { Hanya Tier } \\
1\end{array}$ & 22 & 20 & 91 & 40 & 10 & 30 & 35.50 \\
Hanya Tier & 8 & 18 & 86 & 25 & 8 & 18 & 27.16 \\
$1 \& 3$ & & & & & & & \\
Semua Tier & 7 & 16 & 80 & 19 & 8 & 16 & 24.33 \\
\hline
\end{tabular}

Berdasarkan Tabel 4 dapat diketahui bahwa persentase rata-rata siswa yang mengalami miskonsepsi untuk tingkat pertama yaitu sebesar 35\%, tingkat pertama dan tingkat ke tiga sebesar $27 \%$, sedangkan skor miskonsepsi untuk semua tingkat sebesar 24\%. Dari hasil yang diperoleh dapat disimpulkan bahwa, siswa yang mengalami miskonsepsi untuk materi usaha dan energi digolongkan dalam kategori rendah karena jumlah persentase yang di peroleh $<30 \%$ yaitu sebesar $24 \%$.
Selanjutnya jika Tabel 4 dinyatakan dalam bentuk grafik yang dapat melukiskan persentase ratarata skor miskonsepsi siswa untuk tingkat pertama, kemudian tingkat pertama dan ke tiga serta semua tingkat, maka akan diperoleh hasil seperti pada Gambar 2

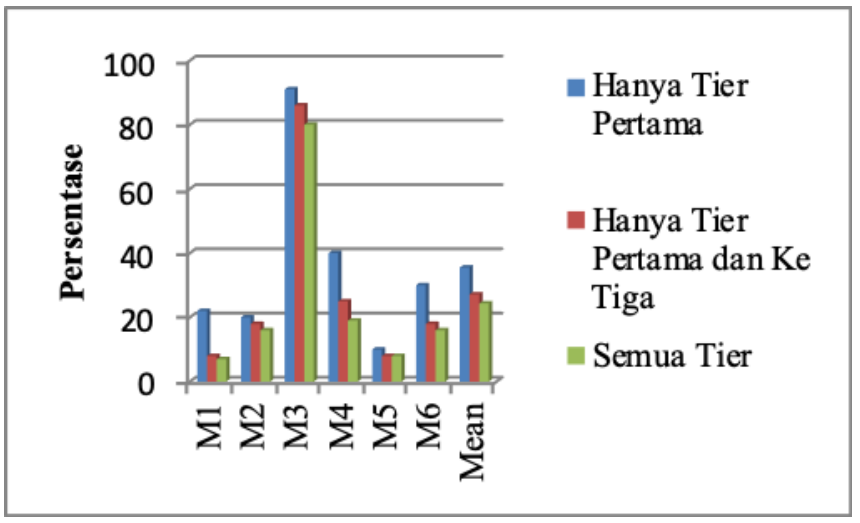

Gambar 2. Persentase rata-rata skor miskonsepsi

Berdasarkan Gambar 2 dapat dilihat bahwa urutan skor miskonsepsi dari yang memiliki persentase tertinggi yaitu skor miskonsepsi untuk tingkat pertama, kemudian tingkat pertama dan ketiga, dan skor miskonsepsi untuk semua tingkat. Pola tampilan skor miskonsepsi yang diperoleh (Gambar 2) bentuknya hampir sama dengan skor benar, yaitu tingkat pertama (tier 1) skornya lebih tinggi. Persentase rata-rata skor miskonsepsi untuk tingkat pertama yaitu sebesar $35 \%$. Persentase miskonsepsi untuk tingkat pertama selalu lebih tinggi karena skor hanya dilihat dari jawaban siswa, tanpa melihat alasan serta tingkat keyakinan dalam memilih jawaban, sehingga apabila siswa menjawab "benar" (sesuai dengan kunci jawaban pada deskripsi miskonsepsi) diberi skor 1. Siswa yang menjawab benar untuk tingkat pertama belum dikatakan sepenuhnya bahwa siswa tersebut mengalami miskonsepsi, karena jawaban benar ada dua kemungkinan. Pertama, siswa menjawab benar karena memang mengalami miskonsepsi. Kedua, siswa menjawab benar karena hanya menebak jawaban.

Skor miskonsepsi untuk tingkat pertama dan ke tiga persentase rata-ratanya sebesar $27 \%$, lebih rendah dari skor miskonsepsi tingkat pertama. Hal ini dikarenakan skor miskonsepsi untuk tingkat pertama dan ketiga penskorannya dilihat dari jawaban dan juga alasan siswa. Apabila jawaban dan alasan benar, diberi skor 1. Kemudian apabila jawaban benar dan alasan salah atau sebaliknya jawaban salah dan alasan benar diberi skor 0. Selanjutnya skor miskonsepsi untuk semua tingkat persentase rata-ratanya yaitu sebesar $24 \%$ lebih rendah dari skor miskonsepsi tingkat pertama dan ke tiga. Hal ini dikarenakan skor miskonsepsi untuk semua tingkat penskorannya dilihat dari jawaban, alasan, dan tingkat keyakinan siswa dalam memilih jawaban dan alasan. Apabila jawaban dan alasan benar, serta tingkat keyakinan dalam 
memilih jawaban dan alasan adalah yakin, skornya 1. Kemudian apabila diantara ke empat tingkat tersebut ada yang salah atau tidak yakin diberi skor 0 .

Jawaban dan alasan yang terdapat dalam setiap item soal dikelompokkan sehingga diperoleh bentukbentuk miskonsepsi pada materi usaha dan energi. Selanjutnya dari bentuk-bentuk miskonsepsi diperoleh hasil persentase miskonsepsi untuk setiap sub konsep materi usaha dan energi beserta pengkategoriannya. Untuk lebih detailnya dapat dilihat pada Tabel 5.

Tabel 5. Persentase Miskonsepsi untuk Setiap Sub Konsep dan Pengkategorian

\begin{tabular}{|c|c|c|c|}
\hline Konsep & Bentuk Miskonsepsi & $\%$ & $\begin{array}{l}\text { Kategori } \\
\text { Miskonsepsi }\end{array}$ \\
\hline $\begin{array}{l}\text { Usaha } \\
\text { positif dan } \\
\text { negatif. }\end{array}$ & $\begin{array}{l}\text { Usaha hanya ditentukan } \\
\text { oleh gaya, jika gaya } \\
\text { positif maka usaha } \\
\text { positif. Suatu usaha } \\
\text { bernilai positif jika arah } \\
\text { perpindahannya ke } \\
\text { kanan, dan usaha } \\
\text { bernilai negatif jika } \\
\text { perpindahannya ke kiri. }\end{array}$ & $23 \%$ & Rendah \\
\hline $\begin{array}{l}\text { Usaha oleh } \\
\text { gaya } \\
\text { konservatif }\end{array}$ & $\begin{array}{l}\text { Semakin sulit atau } \\
\text { semakin panjang suatu } \\
\text { lintasan untuk dilalui, } \\
\text { usaha akan semakin } \\
\text { besar. }\end{array}$ & $85 \%$ & Tinggi \\
\hline $\begin{array}{l}\text { Energi } \\
\text { potensial }\end{array}$ & $\begin{array}{l}\text { Semakin sulit atau } \\
\text { semakin panjang suatu } \\
\text { lintasan yang dilalui, } \\
\text { maka energi potensial } \\
\text { semakin besar. }\end{array}$ & $74 \%$ & Tinggi \\
\hline $\begin{array}{l}\text { Hubungan } \\
\text { antara } \\
\text { energi } \\
\text { potensial, } \\
\text { energi } \\
\text { kinetik, dan } \\
\text { energi } \\
\text { mekanik }\end{array}$ & $\begin{array}{l}\text { Saat benda bergerak } \\
\text { mendekati permukaan } \\
\text { bumi energi potensial } \\
\text { bertambah dan energi } \\
\text { kinetik berkurang. } \\
\text { Energi kinetik atau } \\
\text { energi potensial dari } \\
\text { suatu benda yang jatuh } \\
\text { bebas adalah tetap } \\
\text { karena percepatan } \\
\text { gravitasinya tetap. } \\
\text { Energi mekanik benda } \\
\text { yang jatuh bebas akan } \\
\text { berubah karena } \\
\text { perubahan dari energi } \\
\text { kinetik ataupun energi } \\
\text { potensial. }\end{array}$ & $43 \%$ & Sedang \\
\hline
\end{tabular}

Berdasarkan Tabel 5 menunjukkan bahwa siswa masih mengalami miskonsepsi pada konsep usaha dan energi, diantaranya pada sub konsep:

\section{a. Usaha Positif dan Usaha Negatif}

Siswa yang mengalami miskonsepsi pada sub konsep usaha positif dan negatif digolongkan dalam kategori rendah karena jumlah persentase miskonsepsi yang diperoleh $<30 \%$ yaitu sebesar $23 \%$. Bentuk miskonsepsi yang dialami siswa pada sub konsep ini ada dua bentuk. Bentuk pertama yaitu siswa beranggapan bahwa usaha bernilai positif atau negatif hanya ditentukan oleh gaya, jika gaya positif maka usaha positif dengan jumlah persentase miskonsepsi yaitu sebesar $7 \%$. Siswa berpikir bahwa jika gaya dorong $(\boldsymbol{F})$ arahnya ke kiri maka usaha oleh gaya dorong bernilai negatif dan gaya gesek $(f)$ arahnya ke kanan maka usaha oleh gaya gesek bernilai positif. Selanjutnya bentuk miskonsepsi siswa yang ke dua yaitu suatu usaha bernilai positif jika arah perpindahannya ke kanan, dan usaha bernilai negatif jika arah perpindahannya ke kiri dengan jumlah persentase miskonsepsi yaitu sebesar $16 \%$. Hasil penelitian ini sesuai dengan hasil penelitian Nugraha (2014) yaitu siswa memiliki konsepsi bahwa suatu usaha positif jika perpindahannya ke kanan atau ke atas dan usaha negatif jika perpindahannya ke kiri atau ke bawah.

Miskonsepsi yang dialami siswa pada sub konsep ini dapat disebabkan oleh pemikiran asosiatif siswa. Karena, menurut Liberna (2015) pemikiran asosiasi siswa dapat membentuk kemampuan siswa dalam merespon apa yang telah dilihatnya. Berdasarkan hasil wawancara dengan siswa yang mengalami miskonsepsi mereka mengganggap usaha bernilai positif atau negatif ditentukan oleh arah gaya dan berdasarkan diagram Kartesius. Jika gaya arahnya ke kanan maka usaha bernilai positif dan jika gaya arahnya ke kiri maka usaha bernilai negatif. Menurut Halliday, et al., (2014) usaha $(W)$ merupakan energi yang ditransfer ke atau dari suatu benda dengan perantara suatu gaya yang bereaksi pada benda itu. Energi yang ditransfer ke benda merupakan usaha positif, dan energi yang ditransfer dari benda (objek) merupakan usaha negatif. Sedangkan menurut (Serway \& Jewett, 2018), usaha bernilai (+) jika $\vec{F}$ searah $\vec{s}$ dan bernilai (-) jika $\vec{F}$ berlawanan arah dengan $\vec{s}$. Berdasarkan pendapat tersebut dapat disimpulkan jika gaya yang diberikan searah dengan pergeseran benda maka usaha bernilai positif dan jika gaya berlawanan dengan arah pergeseran benda usaha bernilai negatif.

\section{b. Usaha dan Energi Potensial}

Siswa yang mengalami miskonsepsi pada sub konsep usaha dan energi potensial digolongkan dalam kategori tinggi karena jumlah persentase miskonsepsi yang diperoleh $>60 \%$ yaitu sebesar $80 \%$. Bentuk miskonsepsi dari ke dua soal yang diujikan yaitu siswa beranggapan bahwa besarnya usaha dipengaruhi oleh bentuk lintasan yang dilalui. Berdasarkan hasil wawancara dengan siswa yang mengalami miskonsepsi, semua partisipan yang diwawancarai sependapat bahwa usaha oleh gaya berat dipengaruhi oleh bentuk lintasan. Semakin panjang atau sulit lintasan yang dilalui maka usaha akan semakin besar. Hasil penelitian ini sesuai dengan hasil penelitian 
Nugraha (2014) yaitu siswa menganggap usaha yang dilakukan gaya konservatif lebih besar pada lintasan yang curam. Pada kasus benda meluncur, siswa terlalu fokus pada bentuk lintasan.

Menurut Halliday, et al., (2014) suatu gaya merupakan gaya konservatif jika usahanya pada sebuah partikel yang bergerak diantara dua titik tidak bergantung pada lintasan yang ditempuh partikel tersebut. Gaya gravitasi (berat) dan gaya pegas merupakan gaya-gaya konservatif; gaya gesek kinetik merupakan gaya non konservatif. Selanjutnya Serway dan Jewett (2018) menjelaskan bahwa kerja yang dilakukan oleh gaya konservatif selalu memiliki sifat-sifat berikut yaitu, dapat selalu dinyatakan sebagai perbedaan antara nilai awal dengan nilai akhir dari fungsi energi potensial; bersifat reversible (bisa bolak-balik); tidak tergantung pada lintasan benda dan hanya tergantung pada titik awal dan titik akhir lintasan; dan ketika titik akhir dan awal sama, kerja total yang dihasilkan sama dengan nol.

Berdasarkan beberapa pendapat tersebut dapat diketahui bahwa gaya berat hanya dipengarui oleh massa dan gravitasi. Sehingga bentuk lintasan yang dilalui apakah sulit atau panjang tidak mempengaruhi nilai dari usaha oleh gaya berat.

Selanjutnya berdasarkan hasil wawancara dengan siswa yang mengalami miskonsepsi pada soal berikutnya, semua partisipan yang diwawancarai sependapat bahwa semakin sulit atau semakin panjang lintasan yang dilalui oleh pendaki untuk sampai ke puncak gunung maka energi potensial semakin besar. Ketika mereka ditanya kembali mengapa tidak memilih energi potensial ketiga pendaki sama, mereka sepakat mengatakan energi potensial ketiga pendaki saat tiba dipuncak tidak sama, karena pendaki menempuh lintasan yang berbeda-beda.

Energi potensial yaitu energi yang dihasilkan oleh gaya-gaya yang bergantung pada posisi atau konfigurasi sebuah benda relatif terhadap lingkungannya. Sedangkan energi potensial gravitasi pada sebuah benda, akibat gaya gravitasi bumi, sebagai hasil kali berat benda tersebut, $m g$, dan ketinggian posisi, diatas suatu suatu titik acuan tertentu (semisal permukaan tanah).

Berdasarkan konsepsi tersebut dapat disimpulkan bahwa energi potensial hanya dipengaruhi oleh massa, gravitasi, dan ketinggian. Berdasarkan keterangan soal diketahui bahwa massa ke tiga pendaki sama, kemudian posisi awal dan akhir ketiga pendaki juga sama sehingga dapat disimpulkan bahwa besarnya energi potensial ke tiga pendaki saat tiba dipuncak adalah sama, karena bentuk lintasan tidak mempengaruhi nilai dari energi potensial.

Miskonsepsi yang dialami siswa pada subkonsep ini dapat disebabkan karena reasoning yang tidak lengkap. Kolodner (2014) mengartikan reasoning jenis penalaran analog yang berfokus pada penalaran berdasarkan pengalaman sebelumnya. Reasoning dapat juga terjadi karena logika yang salah dalam mengambil kesimpulan atau generalisasi, sehingga terjadi miskonsepsi. Berdasarkan hasil wawancara dengan siswa yang mengalami miskonsepsi mereka berlogika bahwa semakin sulit atau panjang suatu lintasan yang dilalui akan menyebabkan usaha semakin besar. Selain itu miskonsepsi yang dialami siswa juga disebabkan karena pemikiran humanistik siswa. Partisipan mengatakan bahwa berdasarkan pengalamannya ketika berjalan melewati jalan yang menanjak atau berjalan jauh akan terasa lebih lelah atau capek dari pada berjalan melewati jalan yang datar. Menurut mereka rasa lelah atau capek menyebabkan usaha yang dikeluarkan lebih besar.

\section{c. Hubungan antara Energi Kinetik, Energi Potensial, dan Energi Mekanik}

Siswa yang mengalami miskonsepsi pada sub konsep hubungan antara energi kinetik, energi potensial, dan energi mekanik digolongkan dalam kategori sedang karena jumlah persentase miskonsepsi yang diperoleh berada pada rentang 30\% - 60\% yaitu sebesar $43 \%$. Bentuk miskonsepsi pada sub konsep ini ada tiga bentuk. Bentuk pertama yaitu siswa beranggapan bahwa saat benda bergerak mendekati permukaan bumi energi potensial bertambah dan energi kinetik berkurang dengan jumlah persentase miskonsepsi sebesar 19\%. Bentuk ke dua yaitu energi kinetik atau energi potensial dari suatu benda yang jatuh bebas adalah tetap karena percepatan gravitasinya tetap dengan jumlah persentase miskonsepsi sebesar 8\%. Selanjutnya bentuk miskonsepsi yang ke tiga yaitu energi mekanik benda yang jatuh bebas akan berubah (tidak tetap), karena perubahan dari energi kinetik ataupun energi potensial dengan jumlah persentase miskonsepsi sebesar $16 \%$.

Miskonsepsi yang dialami siswa pada sub konsep ini dapat disebabkan karena pemikiran humanistik siswa. Siswa beranggapan bahwa energi mekanik akan berubah (tidak kekal). Hal ini berdasarkan pengalaman siswa, mereka mengatakan ketika belajar atau bekerja secara terus menerus akan terasa lelah, lapar, dan seperti kehabisan energi. Sehingga mereka beranggapan bahwa energi kekal itu tidak mungkin terjadi, energi yang ada pasti berkurang atau habis.

Berdasarkan miskonsepsi yang terjadi pada siswa maka, untuk meminimalisir miskonsepsi siswa, guru sebaiknya memilih metode pembelajaran yang sesuai dan tepat berdasarkan materi yang akan diajarkan. Selain itu, sebaiknya guru memberikan soal evaluasi yang dapat mengukur atau mengidentifikasi apakah siswa tidak memahami konsep atau mengalami miskonsepsi pada materi yang telah diajarkan. 
Selanjutnya apabila ada siswa yang mengalami miskonsepsi, guru harus segera mengatasi dan meremediasi miskonsepsi siswa.

\section{Kesimpulan}

Berdasarkan hasil penelitian, analisis data, dan pembahasan maka dapat disimpulkan bahwa secara keseluruhan miskonsepsi yang dialami siswa kelas XI MIA SMA Negeri 8 Kota Jambi pada materi usaha dan energi dapat digolongkan ke dalam kategori rendah karena jumlah persentase miskonsepsi $<30 \%$ yaitu sebesar $24 \%$. Urutan sub-konsep yang teridentifikasi miskonsepsi dari yang memiliki persentase tertinggi yaitu: Usaha dan energi potensial (80\%); hubungan antara energi kinetik, energi potensial, dan energi mekanik (43\%); dan usaha positif dan negatif (23\%). Sedangkan pemahaman konsep siswa pada materi usaha dan energi juga digolongkan dalam kategori rendah karena jumlah persentase $<30 \%$ yaitu sebesar $18 \%$. Dapat juga disimpulkan bahwa pemahaman konsep siswa yang rendah tidak langsung berarti bahwa miskonsepsinya tinggi, karena faktor keyakinan siswa terhadap jawaban dan alasan yang diberikan ikut menjadi penentu bagi keduanya.

\section{Daftar Pustaka}

Berek, F. X., Sutopo, S., \& Munzil, M. (2016). Concept enhancement of junior high school students in hydrostatic pressure and archimedes law by predict-observe-explain strategy. Jurnal Pendidikan IPA Indonesia, 5(2), 230-238. https://doi.org/10.15294/jpii.v5i2.6038

Diani, R., Alfin, J., Anggraeni, Y. M., Mustari, M., \& Fujiani, D. (2019, February). Four-Tier Diagnostic Test With Certainty of Response Index on The Concepts of Fluid. In Journal of Physics: Conference Series 1155 (1), p. 012078. IOP Publishing.

Gunawan, I. (2015). Metode penelitian kualitatif: Teori dan praktik. Jakarta: Bumi Aksara.

Halliday, D., Resnick, R., \& Walker, J. (2014). Fundamental of physics (10th ed.). Wiley.

Herliandry, L. D., \& Harjono, A. (2019). Kemampuan Berpikir Kritis Fisika Peserta Didik Kelas X Dengan Model Brain Based Learning. Jurnal Penelitian Pendidikan IPA, 5(1). 1-9. https://doi.org/10.29303/jppipa.v5i1.166

Hidayati, F. N. (2016). Identifikasi Miskonsepsi Siswa Kelas X Pada Materi Elastisitas Dan Hukum Hooke di SMA Negeri 1 Indralaya. Jurnal Inovasi dan Pembelajaran Fisika,3(2). 1-9. https://doi.org/10.36706/jipf.v3i2.3838
Irwansyah, Sukarmin, Harjana. (2018). Analysis Profile of Student Misconceptions on The Concept of Fluid Based Instrument Three-Tier Test. Journal of physics:conf.series 1097. 1-8. https://doi.org/10.1088/17426596/1097/1/012020

Ismail, I. I., Samsudin, A., Suhendi, E., \& Kaniawati, I. (2015). Diagnostik miskonsepsi melalui listrik dinamis four tier test. Prosiding Simposium Nasional Inovasi dan Pembelajaran Sains, 381384.

Jubaedah, D. S., Kaniawati, I., Suyana, I., Samsudin, A., \& Suhendi, E. (2017). Pengembangan tes diagnostik berformat four-tier untuk mengidentifikasi miskonsepsi siswa pada topik usaha dan energi. Prosiding Seminar Nasional Fisika (E-Journal), 6, 35-40. https://doi.org/10.21009/03.SNF2017.01.RND.06

Kaltakci-Gurel, D., Eryilmaz, A., \& McDermott, L. C. (2017). Development and application of a fourtier test to assess pre-service physics teachers' misconceptions about geometrical optics. Research in Science and Technological Education, 35(2), 238-260. https://doi.org/10.1080/02635143.2017.1310094

Khaerunnisak, K. (2018). Peningkatan Pemahaman Konsep dan Motivasi Belajar Siswa melalui Simulasi Physic Education Technology (Phet). Jurnal Penelitian Pendidikan IPA, 4(2). 1-6. https://doi.org/10.29303/jppipa.v4i2.109

Kolodner, J. (2014). Case-based reasoning. Morgan Kaufmann.

Liberna, H. (2015). Membangun Interaksi Edukatif yang Bernilai Normatif melalui Pengajaran Berbasis Aktifitas. Formatif: Jurnal Ilmiah Pendidikan MIPA, 2(2). 1-9. http://dx.doi.org/10.30998/formatif.v2i2.96

Maison, M., Syahrial, Syamsurizal, \& Tanti. (2019). Learning environment, students' beliefs, and selfregulation in learning physics: Structural equation modeling. Journal of Baltic Science Education, 18(3), 389-403. https://doi.org/10.33225/jbse/19.18.389

Nasir, M., Harjono, A., \& Sridana, N. (2015). Pengaruh Pembelajaran Menggunakkan Lks Inkuiri Terintegrasi Generik Sains (Itgs) terhadap Hasil Belajar Fisika Ditinjau dari Motivasi Berprestasi Siswa di Sman 1 Aikmel. Jurnal Penelitian Pendidikan IPA, I(1).1-13 https://doi.org/10.29303/jppipa.v1i1.8

Nugraha, H. A. (2014). Analisis miskonsepsi topik usaha dan energi siswa Kelas XI setelah pembelajaran kooperatif menggunakan simulasi komputer. Universitas Pendidikan Indonesia.

Ramdani, A. (2017). Pengembangan Instrumen Miskonsepsi Kimia pada Konsep Struktur Atom. Jurnal Penelitian Pendidikan IPA, 3(2). 1- 
10. https://doi.org/10.29303/jppipa.v3i2.87

Saheb, W. A., Supriadi, B., \& Prihandono, T. (2018). Implementasi pendidikan karakter dan IPTEK untuk generasi milineal Indonesia dalam menuju Sustainable Development Goals (SDGs) 2030. Prosiding Seminar Pendidikan, 6-13.

Serway, R. A., \& Jewett, J. W. (2018). Physics for scientists and engineers with modern physics. Cengage learning.

Siswadi, S., Susilawati, S., \& Hikmawati, H. (2018). Pengaruh Pendekatan Vak (Visualization, Auditory, Kinestetic) terhadap Hasil Belajar Fisika Siswa SMPN 10 Mataram. Jurnal Penelitian Pendidikan IPA, 4(1). 1-5. https://doi.org/10.29303/jppipa.v4i1.100

Suana, W. (2014). Mengungkap miskonsepsi mekanika mahasiswa calon guru fisika semester akhir pada salah satu universitas di Lampung. Jurnal Pendidikan MIPA, 15(1), 1-8.

Sudarmini, Y., \& Hadiwijaya, A. S. (2015). Pembelajaran Fisika Berbasis Inkuiri Terbimbing dengan Menggunakan LKS Untuk Meningkatkan Keterampilan Berpikir Kritis Ditinjau dari Sikap Ilmiah Siswa Madrasah Aliyah Qamarul Huda Bagu Lombok Tengah. Jurnal Penelitian Pendidikan IPA, l(1). 1-14. https://doi.org/10.29303/jppipa.v1i1.4

Susanti, D., Waskito, S., \& Surantoro, S. (2014). Penyusunan instrumen tes diagnostik miskonsepsi fisika SMA Kelas XI pada materi usaha dan energi. Jurnal Pendidikan Fisika, 2(2).

Wadana, R. W., and Maison. (2019, April). Description students' conception and knowledge structure on electromagnetic concept. In Journal of Physics: Conference Series (Vol. 1185, No. 1, p. 012050). IOP Publishing.

Yang, D., \& Lin, Y. (2015). Assessing 10- to 11-yearold children's performance and misconceptions in number sense using a four-tier diagnostic test. Educational Research, 57(4), 368-388. https://doi.org/10.1080/00131881.2015.1085235

Zafitri, R. E., Fitriyanto, S., \& Yahya, F. (2018). Pengembangan tes diagnostik untuk miskonsepsi pada materi usaha dan energi berbasis adobe flash kelas XI di MA NW Samawa Sumbawa Besar Tahun Ajaran 2017/2018. Jurnal Kependidikan 2(2), 19-34. https://doi.org/10.31227/osf.io/7wyx6 